\title{
REQUESTING SPEECH ACT IN "SERI PENDALAMAN MATERI BAHASA INGGRIS FOR XII GRADE” ENGLISH TEXTBOOK
}

\author{
Ari Nabila ${ }^{1}$ and Fauzi Miftakh ${ }^{2}$ \\ Universitas Singaperbangsa ${ }^{1}$, Karawang, arinabila221@gmail.com \\ Universitas Singaperbangsa ${ }^{2}$, Karawang, fauzi.miftakh@unsika.ac.id
}

\begin{abstract}
This study examines the types of requesting strategies that occur in the English textbook and investigate the context of the dialogues in the textbook. This research employed qualitative content analysis approach. The data were utterances, in the form of sentences, clauses or words that appears in the textbook, while the contexts of the data were the dialogues. Data were obtained through document analysis consisting of nine request strategies. The data were analyzed by determining the request strategies based on Trosborg's theory (1995), and context of situation theory by Holmes (2001). The result shows that there are eight strategies of requesting found within the textbook. The types that appears most frequently within the textbook is questioning ability/willingness and the slightest showing up is mild hints and suggestory formulae. A few sorts are also found such as, imperatives, demands/needs, wish, permissions, and strong hints. The data showed, understanding speech acts also means understanding how language is used and practiced or, in other words understanding the context. Thus, misunderstanding and misinterpretation can be minimized.
\end{abstract}

Keywords: Requesting, Speech Act, Context of Situation, Textbook

\section{INTRODUCTION}

In Niezgoda \& Rover's (2001) research updates to Bardovi-Harlig and Dörnyei (1998) which looked at grammatical errors and pragmatic errors in the context of ESL and EFL learners, it was found that the level of pragmatic error measured by ESL learners was more significant than grammatical error, while the level of error measured by EFL learners was the same as grammatical and pragmatic. It shows that student awareness and pragmatic production are an important aspect to be examined in the field of language-to-language pragmatism (Aribi, 2014). Pragmatics has two primary aspects, namely speech acts and politeness strategies in the text; however, the speech act has been extensively examined with regard to the ESL and the EFL (Aribi, 2014). Since the Speech Act is defined to be used in the communication to obtain an in-depth interpretation for others, the Speech Act must be considered by all educators when selecting the primary material for teaching in the textbook. As Vakilifard, et al (2015) explained, the previous study of the speech acts in the textbook has shown that the textbook has the opportunity to teach pragmatic students.

Researchers have observed, in recent decades, that the frequency of presence of the request speech act in the book is high. Therefore, this research was inspired by previous research carried out by Akutsu (2006) in EFL textbook research, which also found that EFL textbooks use the right strategy when applying requests for speech acts and measuring the percentage of excessive request 
strategies utilization. However, the gap between the current research with Akutsu (2006) is the use of the taxonomy that classified the request. Akutsu (2006) uses Request strategies by NSs and NNSs to conduct the research but this current research would like to use the taxonomy by Trosborg (1995). Trosborg classified four situations that mostly happen in daily life and the availability of many situations allows many types of requests that can be expressed in the dialogue contained in this book, which is the reason for this study using taxonomy by Trosborg (1995). In the context of the EFL, textbooks are seen as a crucial element of teaching languages for materials that provide authentic examples of speech act to develop pragmatic skills in EFL students (Farashaiyan, 2017).

Indeed, in many cases, foreign language students only have the opportunity to obtain aspects of pragmatic discourse from foreign languages in context teaching. Thus, it is important to identify the taxonomy of requesting speech act and contextual of information about the request speech act in the textbook in order to inform students of requesting the learning of speech acts. This research examines how both can be related-assessing the use of the Speech Act in the English textbook. The researcher composes the following research questions for that purpose: 1) What kinds of requesting speech act strategies exist in the "Seri Pendalaman Materi Bahasa Inggris for XII grade" English Textbook? 2) What are the context of situation that happen in the "Seri Pendalaman Materi Bahasa Inggris for XII grade" English textbook?

\section{LITERATURE REVIEW}

\section{Requesting Speech Act}

Generally, the Speech Act is an expression that forms an act of the speaker to the interlocutor. Austin (1962) suggested three forms of speech that could be categorized as a speech act, such as Locutionary, Perlocutionary, and Illocutionary. These three types of speech act have their features, which are defined by their basic structure (directive or indirect speech act). Request is one of the acts of speech recognized as an Illocutionary speech act. Therefore, a request is a polite way for asking something. In accordance with Brown and Levinson (1978), the request is an action that threatens the face where the speaker and the faces of listeners are risky. There are several theories about request strategies, such as positive politeness and negative politeness strategies by Yule (1996). Also, there are "On-Record and "Off-record" strategies by Brown and Lavinson (1987).

However, this research will use another speech act strategies developed by Trosborg (1995). Trosborg's strategies include four conditions that most commonly arise in real life, namely Indirect Request, Indirect (Hearer-Oriented Condition), Indirect (Speaker-Oriented Condition), Direct Request. There are several strategies, such as Hints, Questioning/statements of ability/ willingness, Permissions, Suggestory formulae, Statements of speaker's wishes and desires, Statements of speaker's needs and demands, Statements of obligation, Performative, Imperatives, and Elliptical phrases.

\section{Requesting Taxonomy by Trosborg (1995)}

Trosborg (1995:192) states that there are a variety of request techniques, such as: 


\section{Hints}

In this types of request, the speaker hides his request and does not make a clear reference to the request in the speech. In certain words, make those meanings implicitly, as described by Fahrurrozi (2015), that by making a statement, the speaker 's request may imply to the listener what he wants. When interpreting commands, it is always important to have intimate knowledge of others, to have basic context information, and to find out certain situational features, etc., there are two kinds of hints that are mild and solid. There are 2 kind of hints, namely Mild and Strong.

\section{Questioning Ability/Willingness}

If this technique is introduced by the speaker, the question posed by the speaker is supposed to be answered by the listener. It involves a change from questions about the ability or will of the respondent to the requester. It is also up to the listener whether or not the request is made. Intensification, such as likes, compassion, thoughts and objects, can be considered a prerequisite for willingness. In accordance with Trosborg (1995), this is an indirect communication technique that refers to the capacity / will of the listener to take the desired action. Request strategy's willingness to understand the willingness of the respondent to take the desired action.

\section{Permissions}

Trosborg (1995) states that permission requests can also be used to request the willingness of listeners to respond to requests. This question requires a change in emphasis that is directly disrespectful to the speaker as the subject or object of the operation, rather than to the listener as the agent of action. In addition, requests can be included in expressions of gratitude, desires, etc. on behalf of the applicant.

\section{Suggestory Formulae}

By using a suggestory formula, the applicant should not feel obligated to question a particular situation dependent on the listener, but instead to give guidance on the argument of the request. Through presenting a demand through a provocative process, the speaker makes his request more deliberate and discourages his own involvement as the beneficiary of the intervention.

\section{Statement of Speaker`s Wishes}

Desire of the speaker is the control of this technique. It is generally conveyed in a respectful way, so that the listener does not feel compelled to comply with the action requested. For example, "I want you to clean up today." This request is made by reminding the speaker of the wishes (Fahrurrozi, 2015).

\section{Statements of Speaker`s Need and Demand}

Speakers who use this technique tend to be more straightforward because demand has a high degree of taxation. As a consequence, the listener is required to 
make the request. Nonetheless, this request technique can be made friendlier by adding "Please" or other mitigation methods.

\section{Statements of Obligations}

The speaker uses his authority by using this technique. The use of this technique uses auxiliary verbs such as, have, should, and must, mark statements as requests. The arrangement would have moral responsibilities.

\section{Performatives}

Through this technique, the use of performative verbs that communicate the intent of the request, such as demanding, asking, ordering, requesting, ordering, etc., specifically describes the expression as a performative request. Performative comments with the intention of questioning are rather straightforward and typically authoritative. The proposal was less respectful than the declaration of duty and need. Nevertheless, if the applicant wants to soften the sentence of that request, it is possible to safeguard the unheard-of power of that argument, it is often referred to as the Hedged performative.

\section{Imperatives}

The imperative is a type of speech act which directly implies that speech is a command in its unmodified and highly authoritative type. Listeners have to do what the speaker needs, because the speaker has control over the audience. In addition, Elliptical Phrase is another type of imperative, but it uses a type of elliptical phrase.

Table 1. Requesting Taxonomy by Trosborg (1995)

\begin{tabular}{|c|c|}
\hline \multicolumn{2}{|c|}{ Situation } \\
\hline \multicolumn{2}{|c|}{ Indirect Request } \\
\hline \multirow{2}{*}{ Hints } & Mild \\
\hline & Strong \\
\hline \multicolumn{2}{|c|}{$\begin{array}{l}\text { Indirect (Hearer-Oriented } \\
\text { Condition) }\end{array}$} \\
\hline \multicolumn{2}{|c|}{ Ability /Willingness } \\
\hline \multicolumn{2}{|c|}{ Permission } \\
\hline \multicolumn{2}{|c|}{ Suggestory Formulae } \\
\hline \multicolumn{2}{|c|}{$\begin{array}{ll}\text { Indirect } & \text { (Speaker-Oriented } \\
\text { Condition) } & \end{array}$} \\
\hline \multicolumn{2}{|l|}{ Wishes } \\
\hline \multicolumn{2}{|c|}{ Desires/needs } \\
\hline \multicolumn{2}{|c|}{ Direct Request } \\
\hline \multicolumn{2}{|c|}{ Obligation } \\
\hline \multicolumn{2}{|c|}{ Performatives } \\
\hline & Hedged \\
\hline Imperatives & Unhedged \\
\hline Elliptical Ph & \\
\hline
\end{tabular}




\section{Context of Situation}

Context plays an important part in communication. The utterance can only be the utterance when there is no meaning on it. Yule (1996:21) suggests that the physical environment or 'context' is perhaps more conveniently recognized as having a significant effect on the understanding of referring words. The meaning of the situation is the climate, time and place, and so on. Where the speech takes place, and also the relationship between the participants - the first explanation (1950) in M. A. K. Halliday and Ruqaiya Hasan (1989) on the context of the situation include: (1) Participants refer to individuals and personalities with sociological status and roles; (2) what actions are taken, including verbal and non-verbal acts; (3) other specific situational characteristics of the object around and events related to what is occurring, and the effects of verbal behavior on what changes are generated by what is said.

Furthermore, the context of situational suggested by Holmes (2001) has the same aspects as those advocated by other theories, but this theory distinguishes certain aspects in detail, and so this analysis uses the theory put forth by Holmes (2001). Holmes (2001:8) affirms that, in any case, linguistic choices will usually indicate the effect of one or more of the following elements:

a. Participants: who speaks and with whom he talks.

b. The Setting or Social Context of Interaction: where they are (physical setting) and the psychological situation in which they are speaking.

c. The Topic: what they're talking about.

d. The Function: why they're talking.

These are fundamental elements in a realistic description of why people don't all talk the same way all the time.

\section{English Textbook}

The textbooks are also meant to complement a particular academic course or content to be read by the students. The instructor assumes that students need textbooks and material, and that the textbook is adequate to meet the needs of students (Richards, 2001; Grave, 2000). Likewise, the importance of books in the learning of languages. Knowledge building for students is one of the main areas of research in textbook research covering the various scientific fields of language studies and education.

Textbooks can be described as books that contain content, if necessary, written for teaching and learning purposes. Textbooks are important items students need to have. While there is a clear connection between textbooks and students, the explanation of how students use their textbooks still shows little evidence, and several factors need to be considered when choosing textbooks for students. A number of considerations need to be weighed in the choice of student textbooks. Cunningsworth (1995) classifies four conditions in the assessment of each book to be included.

a. The material of the textbooks should be made up of all the needs of the learners.

b. Textbooks must represent the use of language on the basis of various circumstances in real life.

c. The textbook must take into account the needs of students and must promote their learning without implementing particular methods. 
d. Textbooks will have a distinct function as a tool to promote learning. This means that the vocabulary given by the textbook will represent a language that is easy to understand to help learners understand the materials.

In addition, textbooks are important in terms of learning and are still the most common source of knowledge transfer to students by all language teachers in their classrooms. It is therefore expected that the analysis of this textbook will support the development and success of curriculum development and new teaching and learning initiatives in the field of pragmatic learning, particularly in the speech act.

\section{METHOD}

This research examines the use of speech in "Seri Pendalaman Materi Bahasa Inggris for XII Grade" English Textbook written by Elly Sofiar, and Eka Mulya Astuti English. The speech act of the request in the textbooks is analyzed by means of a qualitative analysis of the content. Qualitative content analysis has a textual method that is useful for classifying a code based on cause or effect. For example, by analyzing the number of times a word is written or spoken. Content analysis can be used to test large volumes of text using exact techniques by reducing the amount of data and the data is divided up into a group of information or smaller expressions in the form of a code.

Creswell (2007: 184) notes that the researcher himself is the key tool of the experiment. The researcher plays the role of planner, data collector, analyst, interpreter and research findings reporter. In addition to the main instrument, the data sheet is used to document linguistic anomalies contained in every expression, phrase or dialog contained in the textbook and is often used as a secondary tool. The instrument used in the form of a code that reflects the information sought by researchers with the intention of facilitating the collection of data.

Thus, the researcher has eight steps to retrieve data in accordance with the theory of document analysis. Data from textbooks related to the request for speech acts was collected and gathered. After the data is gathered, the data are put together in a code. The final step is the proper and transparent interpretation and presentation of the data when reporting the findings.

The methodology used in this study to analyze the data is the model of analysis that detects the phenomenon in the data and classifies it into similar present themes (patterns). There are three steps in using this methodology based on Miles \& Huberman (1994), namely: Data Reduction, Data Display, Data ConclusionDrawing / Verification.

\section{Data Reduction}

Researchers need to document data through data reduction carefully and in detail throughout the data reduction process. Reducing data means that the researcher decides what important issues are relevant to the topic and the trend. Thus, the data has been reduced in order to provide consistent representation and to make it easier for researchers to collect data. The researcher reduced the data by a variety of steps, i.e.: 1) after being collected from field observations, the researcher edited the results of the data; 2) after editing the report, all the data is 
segmented; 3) the report summarizes the data in the notes; 4) the researcher chooses what is correlated with essential statements with the dominant speech act of the requester.

\section{Data Display}

The researcher organizes, compresses and collects knowledge. Once the data has been reduced, the researcher gathers the data presented in the textbook, including the requirement for a speech act and the situational meaning that exists in each dialog. This research uses a table to display the data found. The table serves to clarify the delivery of complex data in the research results. The table contains simplified data and shows the frequency of data found.

\section{Conclusions/Verification}

The explanation for the reduction and retrieval of data is to help draw conclusions. Only two steps have been taken, namely data reduction and data presentation for the latter, and the researcher draws conclusions based on the data that has been analyzed in order to make it easier for readers to know the results of the study more easily.

\section{FINDINGS AND DISCUSSIONS}

\section{Findings}

1. The Types of Requesting Speech Acts Exist in the "Seri Pendalaman Materi Bahasa Inggris for XII grade” English Textbook

After identified the textbook which is limited to dialog situations, it found that there are 8 forms of requesting speech acts contained in "Sari Pendalaman Materi Bahasa Inggris for XII Grade deep dialogs. They are Mild Hints, Strong Hints, questioning Ability / Willingness, Permisson, Wish, Demand / Need, Hedged Performatives, and Imperatives.

\begin{tabular}{|c|c|c|c|c|}
\hline No. & $\begin{array}{l}\text { Classification of Requ } \\
\text { Speech Act }\end{array}$ & sting & Frequency & Percentage \\
\hline \multirow[t]{2}{*}{1.} & \multirow{2}{*}{ Hints } & Mild & 4 & $3,5 \%$ \\
\hline & & Strong & 7 & $6,2 \%$ \\
\hline 2. & $\begin{array}{l}\text { Questioning } \\
\text { Ability/Willingness }\end{array}$ & & 56 & $49,6 \%$ \\
\hline 3. & Permission & & 9 & $8 \%$ \\
\hline 4. & Suggestory Formulae & & 4 & $3,5 \%$ \\
\hline 5. & Wish & & 8 & $7,1 \%$ \\
\hline 6. & Demand/Need & & 7 & $6,2 \%$ \\
\hline 7. & Imperatives & & 18 & $15,9 \%$ \\
\hline Tota & & & 113 & 100.0 \\
\hline
\end{tabular}

Table 2. shows that there are eight types of requesting speech acts that are used by characters in dialogue. Questioning ability / willingness get the highest data with 56 data or 49, 6\%. Questioning ability / will is the Requesting Speech 
Act that is most widely known since, generally, this type of request is the most common by addressing the request respectfully and not explicitly. The second highest number is occupied by imperatives with 18 data or $15.9 \%$. This form of request for a speech act also needs to be given to students, as it is in order to state the request for a sentence in everyday life. The third number is permission with 9 data or $8 \%$. Wish obtained 8 data or $7,1 \%$ of the existing dialogue. The fifth is Demand/Need occupies the next position with 7 data or $6,2 \%$. Furthermore, Hints have two types, namely Mild Hints get 4 data or 3, 5\% and Strong Hints get 7 data or $6,2 \%$. Hints are a form of request that is not direct or delivered implicitly. Last but not least, there is a Suggestory Formulae that gets as much as 4 or 3, 5\% data. These types of requesting usually contain a suggestion sentence what the listener should do.

2. The context of situations of speech act happening in the textbook

Context ultimately decides the interpretation of the data, whether it is the person, the environment, the subject and the purpose. In the textbook, it influences the meaning of the conversations that happened. Regarding the context of situation, the results showed that the meanings used and revealed in the dialogs are varied. The people participating in the dialogs are varied. It's always between friends, customer service, assistant, and a stranger. The physical settings in the dialogs are often varied. It's usually over the phone, in the street, in the home, and in the office. Psychological settings are mostly friendly, warm and pleasant, as most of the participants are between friends. The topics discussed in the dialogs are commonly related to issues that have been identified in daily life. The functions expressed in conversations are then needed to be learned by the students in order to be practiced in their daily lives.

\section{Discussion}

It is as new data in the previous study, as Akutsu (2006) said, that speech acts were found in the EFL book in a fairly high percentage of requests for strategies. Speech act is not only a choice of terms and phrases, it also includes the meaning directly used in a discussion between the speaker and the listener as to how they behave in the use of language.

a. Mild Hints

\begin{tabular}{|l|l|}
\hline SC) (U:1/P12/T6/ & Woman: Can you help me? \\
& Man: Sure. How can I help you? \\
& Woman: I need to go to Melbourne. \\
& Man: That train is on track 2. \\
& Woman: Thank you. \\
& Man: You're welcome. \\
\hline
\end{tabular}

\section{Context of situational:}

The conversation takes place in the station. The participants are Woman and Man, they don't know each other. The atmosphere of the conversation is warm and polite as where they are strangers to each other and only meet for the first time. They talk about how to get the track where the train to Melbourne stops. It seems that the woman doesn't know about train track's information so she asks the man. 
Analysis of request strategies:

Based on the analysis of context of situational. Woman's utterance is Mild hint strategy. By making statement "I need to go to Melbourne" she doesn't only make a statement but also ask something. Indirectly she wants the man to tell her the train track's to go to Melbourne, she want to know how to get there. The speaker hides her motive to the hearer, so it will reduce the power of request. It seem from the sentence. As stated by Fahrurrozi (2015) in interpreting the utterance of hints requesting. Paying attention to the context of situational is the right way to find out what the meaning contained in a sentence that is expressed.

b. Strong Hints

\begin{tabular}{|r|l|}
\hline (U:1/ & Andy: Excuse me. Where is the bookstore? \\
P11/T5/SC) & Awan: It's on the third floor. It's next to the supermarket. \\
\hline
\end{tabular}

\section{Context of Situation:}

In the mall, Andy and Awan meet for the first time. It makes the situation of the conversation is polite and brief. They are talking about the location of the book store because Andy want to go to the bookstore but he didn't know the location. The intention of Andy's question is requesting as a strong hints.

\section{Analysis of request strategies:}

The illocutionary intent cannot be inferred directly from the locution; however, the locution refers to the related elements of the intended illocutionary and/or propositional act. Andy's utterance is a strong warning structure. What he said, "Where is the book store" is Andy's strategy, indirectly, to get to know where the book store is located. As it in line with Trosborg (1995) when the speaker uses strong hints, the speaker hints at his motive. The speaker wants to go to the bookstore, but he doesn't force the request.

c. Questioning Ability or Willingness

\begin{tabular}{|l|ll|}
\hline $\begin{array}{l}\text { (U: } \\
\text { 1/P24/T12 } \\
\text { /SC) }\end{array}$ & are? & $\begin{array}{l}\text { Tini: Can you tell me where the latest Dan Brown novels } \\
\text { Shopkeeper: They are in the book best-selling section, aisle } \\
\text { three. }\end{array}$ \\
& \multicolumn{2}{|c|}{ Tini: They're on sale today, aren't they? } \\
\hline
\end{tabular}

\section{Context of Situation:}

This conversation was held in the bookstore. The participant is Tini and Shopkeeper, who talk to the shopkeeper in a friendly way. The subject of the discussion is the location of the new Dan Brown novels. Tini is looking for the new Dan Brown books and asks the store clerk to tell her where the book is.

\section{Analysis of request strategies:}

Tini 's utterance counted as requesting of questioning ability or willingness. Tini said, "Can you tell me where the most recent Dan Brown books are?" It means that Tini believes the shopkeeper has the ability to tell her where the latest Dan Brown novels are. As in line with Trosborg (1995) when the speaker uses strong 
hints, the speaker hints at his motive. The speaker wants to go to the bookstore, but he doesn't force the request.

d. Permission

\begin{tabular}{|c|l|}
\hline (U:1/ & Waiter: Excuse, me. May I take your order? \\
P12/T6/SC) & Girl: Yes. I'd like to order a beef burger and french fries. \\
& Waiter: Anything else? \\
& Girl: A glass of orange juice, please. \\
\hline
\end{tabular}

\section{Context of Situation:}

The talk took place at the restaurant. The participant in this discussion is a waiter and a child. The environment created by the conversation is polite and caring. Since the waiter has to be polite to all the customers. The girl selected a menu, and the waitress asked if the waiter could take orders from the girl. The intentions of the waiter is requesting as permission.

Analysis of request strategies:

Trosborg (1995) explained Permission is how the speaker delivers the utterance still implicit and express the request sentence by asking or asking permission from the listener first. Waiter's question reveals the permission technique. While asking "Can I take your order?" as the waiter's tactic to get the girl's permission to give her orders to the waiter. The word "Can" is also a hint, as the use of the word "may" is typically used to express permission.

e. Suggestory Formulae

\begin{tabular}{|l|c|}
\hline \multicolumn{1}{|c|}{$(\mathrm{U}$} & Ani: I was thinking of holding the company retreat in \\
$: 1 / \mathrm{P} 31 / \mathrm{T} 1$ & Bandung. \\
$6 / \mathrm{SB})$ & Luky: I was just going to say that. That would be perfect. \\
& Ani: We'd better ask the staff's opinion regarding the \\
& venue.
\end{tabular}

\section{Context of Situation:}

Ani and Lucky are a colleague of mine. The atmosphere of the conversation is intense, but warm, because they are close to each other. Anita and Lucky thought to stage a business retreat in Bandung. So they have the idea of keeping a company, but they want to ask the workers before they take a decision. They are still considering the idea, and Ani suggests that it is much better to discuss it with the staff before reaching an agreement.

\section{Analysis of request strategies:}

Ani 's question in the last conversation indicates a technique with suggestive formulas. By saying, "We'd better ask the staff's opinion regarding the venue," Bella suggests to Lucky that they ask for the opinion of the matter. This also shows in the words, "We'd better" that getting the idea out of the stuff would be a lot easier. As it is line with Trosborg (1995) Suggestory formula is submitting the utterances that contain suggestions to do something. 
f. Requesting as a statement of wish

\begin{tabular}{|c|c|}
\hline U:2/ & Rudy: I'd like to make an appointment with dr. \\
P152/T5/RS & $\begin{array}{c}\text { Purnomo tomorrow. } \\
\text { Sita: He is out of town until Tuesday. He'll be back on } \\
\text { Wednesday morning. } \\
\text { Rudy: Is he available on Wednesday evening? }\end{array}$ \\
\hline
\end{tabular}

\section{Context of Situation:}

The Participant of this conversation is Rudy and Sita, they're talking politely. It seems that Rudy wants to make an appointment with Dr. Purnomo, but sadly Dr. Purnomo is out of town until Tuesday. Rudy could make a meeting with Dr. Purnomo until Dr. Purnomo returned to town on Wednesday morning.

\section{Analysis of request strategies:}

Rudy expresses the sentence of the request as a wish, as seen in the sentence "I'd like to make an appointment with Dr. Purnomo tomorrow." Rudy hopes he will be able to meet Dr. Purnomo. The term "I'd like" means that the speaker needs the listener to agree with his wishes. As in line with Trosborg (1995) in this strategy, the wishes of the speaker become the focal point of the interaction. This form of demand strategy is obvious, but it has no clear definition. Seeing the participants, Dr. Purnomo is in a higher position than Rudy, so he cannot be forced by Rudy.

\section{g. Requesting as Demands/Need}

\begin{tabular}{|c|c|}
\hline (U:1/P21/T11/SC) & $\begin{array}{r}\text { Mr. Smith: Something is not right here. } \\
\text { Why are these figures added to the proposal? } \\
\text { Selly: Hmm. Let me read it. I don't think } \\
\text { this is what we agreed. } \\
\text { Mr. Smith: That's it. We really need to } \\
\text { discuss this with the finance manager }\end{array}$ \\
\hline
\end{tabular}

\section{Context of Situation:}

Mr. Smith and Selly have a serious discussion in the office about the proposal. There are some flaws in the plan that seem to have not been accepted before. Mr. Smith complained that there were additional figures in the budget and he decided to discuss this with the finance manager.

\section{Analysis of request strategies:}

Mr. Smith makes his request by requesting it. He applies his request bluntly as a request. According to the background, she's a little frustrated that there's something wrong with the proposal. He made his request by saying, "That's it. We really need to speak to the finance manager about this. As in line with Trosborg (1995) that states demand/needs strategy is an expression when the speaker's request more and more frankly as request. 
h. Imperative

\begin{tabular}{|l|r|}
\hline \multicolumn{1}{|c|}{ U } & Secretary: I'm sorry. Mr. Hamid is in a meeting right now. \\
$:$ /P209// & Mr. Ahmad: Can I speak with him? I think he needs to \\
T9/RS & $\begin{array}{r}\text { answer these questions directly. } \\
\text { Secretary: I'm sorry, I can't interrupt the meeting. I can take } \\
\end{array}$ \\
& $\begin{array}{r}\text { a message or I can try to answer your questions. } \\
\text { Mr. Ahmad: All right, then. Please tell him to call me back. }\end{array}$ \\
\hline
\end{tabular}

\section{Context of Situation:}

Secretary and Mr. Ahmad are talking respectfully over the phone. Mr. Ahmad appears to want to talk to Mr. Hamid, because there is something he needs to know, but Mr. Hamid is in a conference, so the secretary does not disturb the conference. So, Mr. Ahmad leaves a message to the secretary to tell Mr. Hamid to call him back after the meeting.

\section{Analysis of request strategies:}

Mr. Ahmad's statement, "Please tell him to call me back" may indeed be classified as imperatives. Thus, Mr. Ahmad demonstrates that his power or position is higher than the secretary and equivalent to Mr. Hamid, as the secretary has to tell Mr. Hamid to call Mr. Ahmad back. The word "Tell him" signaling that this utterance is an imperative requesting. Trosborg (1995) explained that imperatives are a request strategy that directly signifies that the utterance is ordered.

The result found is as new data in the previous research, which Akutsu (2006) said, that speech acts were found in the EFL book in a fairly high percentage on requesting strategies. Requesting speech act and the context of the situation are closely related. It is not only a combination of terms and phrases, it also includes the meaning directly used in a discussion between the speaker and the listener as to how they behave in the use of language. Context that happens in a conversation may make the meaning of a word different. Yule (1996: 21) says that meaning has a strong effect on how the terms of reference are to be perceived.

In addition, the observation of the high frequency of requests of speech in the book and the varied contexts of the situation indicate that this book represents the use of language in the real world in a variety of circumstances, which is one of the criteria used in the evaluation of books cited by Cunningsworth (1995). Moreover, this has benefits in the pedagogical areas which have shown that the book used is appropriate to meet the needs of students. The textbook, which includes many requesting speech act and context of situation, helps students to consider various types of circumstances and how students should use requests in appropriate context, as it is one of the key competencies that the students will obtain.

\section{CONCLUSIONS}

Two conclusions can be drawn in this study, based on the findings and discussions. The results reveal eight of Trosbrog's (1995) four types of speech act techniques used by the characters in dialog in the textbook entitled "Seri Pendalaman Materi Bahasa Inggris for XII Grade" and written by Elly Sofiar, and Eka Mulya Astuti 2018. Questioning ability / willingness type of request speech act has the most data, and mild request and suggestory formulae have the fewest 
data than the other request approaches that exist in the textbook. Meanwhile, there is no, performative, elliptical sentences, and obligation do not appear in the dialog. Regarding the context of situation, the result revealed that the correlation between the requesting strategies and the context of the situation is very important in determining the in-depth meaning of the conversation.

Regarding to the implications, interventions and implementation of the teaching or assessment of English textbooks, this work demonstrates that it is important to carry out a thorough study of the demands for speech acts and their context in order to interpret the meanings of the statements successfully. Understanding speech also requires understanding how the language is used and learned.

\section{REFERENCES}

Akutsu, Y. (2006). Request Strategies in 'Oral communication A' Textbooks. The Economic Journal of Takasaki City University of Economic, 135-149.

Aribi, I. (2014). Analysis of the speech act of request in EFL materials. International Journal of Learning and Teaching, VI(1), 13-29.

Austin, J. L. (1962). How To Do Things With World. London: Oxford University Press.

Brown, P. \&. (1978). Universals in language usage: Politeness phenomena. In Questions and politeness: Strategies in social interaction. (In E. N. (Ed ed.). Cambridge: Cambridge University Press.

Creswell, J. W. (2007). Qualitative Inquiry and Research Design: Choosing Among Five Approaches (2nd ed.). Thousand Oaks, California: Sage Publications.

Cunningsworth, A. (1995). Choosing Your Coursebook. Oxford, UK: Macmillan Heinemann.

Delen, B., \& Tavil, Z. M. (2010). Evaluation of four coursebooks in terms of three speech acts: Requests, refusals and complaints. Procedia Social and Behavioral Sciences, 692-697.

Fahrurrozi, M. R. (2015). A Pragmatic Analysis of Speech Act of Request Expressed by the Characters in Office Space. Yogyakarta: YOGYAKARTA STATE UNIVERSITY.

Farashaiyan, A. (2017). The Linguistic Presentation of Speech Acts in. International Journal of Linguistics, IX, 166-186.

Holmes, J. (2001). An Introduction to Sociolinguistic. London: Longman Group.

Khoirunnisa, J. W. (2017). An Analysis of Representative Speech Act In Teaching and Learning Procress on the Speaking Class of the Third Semester in English Department of IAIN Surakarta. Surakarta: The State Islamic Institute of Surakarta.

Miles, M. \&. (1994). Qualitative data analysis: an expanded sourcebook. California, U.S.A: Sage Publications. 
Niezgoda, K. \&. (2001). Pragmatics in language teaching. In K. Rose, \& G. K, Pragmatic and grammatical awareness: A function of the Larning environment? (pp. pp. 63-79). Cambridge, England: Cambridge University Press.

Siddiqui, A. (2018). The principle features of English Pragmatics in applied linguistics. Advances in Language and Literary Studies., IX(2), 77-80.

Takahashi, S. (1996). Pragmatic transferability. . Studies in Second Language Acquisition, 189-223.

Trosborg, A. ((1995). Interlanguage Pragmatic. Request, Complaint, and Apologies. Berlin: Mouton de Gruyter.

Vakilifard, A. E.-M. (2015). A Critical Analysis of Speech Acts in Textbooks of Teaching Persian to Speakers of Other Languages. English for Specific Purposes World, 1-23.

Yule, G. (1996). Pragmatics. Oxford: University Press. 